\title{
ELŻBIETAMAGIERA*
}

\section{„Młody Spółdzielca” - czasopismo propagujące wychowanie spółdzielcze}

\section{Ogólna charakterystyka czasopisma}

Miesięcznik „Młody Spółdzielca” opatrzony podtytułem „Przewodnik dla Spółdzielni uczniowskich” był wydawany przez „Społem” Związek Spółdzielni Spożywców Rzeczpospolitej Polskiej (ZSSRP) w latach 1936-1939 w Warszawie przy ul. Grażyny 13. Adresatem tego miesięcznika były dzieci i młodzież należąca do spółdzielni uczniowskich i zainteresowana działalnością tych organizacji oraz ich opiekunowie ${ }^{1}$. Pierwszy numer czasopisma, który ukazał się w marcu 1936 r., rozesłano bezpłatnie do szkół powszechnych wyżej zorganizowanych, szkół średnich ogólnokształcących i zawodowych². Zarządzeniem Ministerstwa Wyznań Religijnych i Oświecenia Publicznego z dnia 29 lipca 1937 r. „Młody Spółdzielca” został zatwierdzony do użytku wyższych klas szkoły powszechnej i niższych gimnazjum. Prenumerata jego za rok szkolny wynosiła 2 złote.

W latach 1936-1938 redaktorem naczelnym czasopisma był Karol Haubold. Komitet redakcyjny stanowiły znane i zasłużone dla polskiego ruchu spółdzielczego dorosłych i młodzieży szkolnej następujące osoby: Franciszek Dąbrowski, Franciszek Dippel, Józef Dominko, M. Waseńczuk, Jan Wolski, a od drugiego numeru pisma w skład komitetu redakcyjnego weszła Hanna Dobrowolska. W 1938 r. K. Haubold został redaktorem odpowiedzialnym, a H. Dobrowolska kierowniczką pisma. Od 1939 r. funkcje redaktora naczelnego sprawowała H. Dobrowolska. W latach międzywojennych wydano 30 zeszytów „Młodego

* Dr hab., Katedra Historii Wychowania, Instytut Pedagogiki, Wydział Humanistyczny, Uniwersytet Szczeciński, 71-431 Szczecin, ul. Ogińskiego 16/17.

1 Więcej o wychowaniu spółdzielczym i spółdzielczości uczniowskiej w okresie międzywojennym: E. M a g i e r a, Spółdzielczość jako forma edukacji w szkolnictwie polskim Drugiej Rzeczypospolitej (1918-1939), Szczecin 2011.

2 „Młody Spółdzielca” [dalej: MS] 1936, nr 1, s. 14. 
Spółdzielcy", z czego w 1936 r. ukazały się 4 numery, w 1937 r. i 1938 r. po 10 numerów i w 1939 r. 6 numerów. Od 1 września 1938 r. zmieniono szatę graficzną czasopisma, otwarto kącik, w którym publikowano prace dzieci, wydzielono „Przewodnik dla Opiekunów Spółdzielni Uczniowskich” oraz wprowadzono dział prac i robót dla dzieci i młodzieży oraz kącik twórczości i rozrywki dziecięcej.

Autorami tekstów dla dzieci i młodzieży byli: Edward Szymański, Olena Haubold, Maria Dąbrowska, Tadeusz Poźniak, Józef Woszczak, Ewa Szelburg-Zarębina, Benedykt Hertz, Roman Kluge, Maria Orsetti, Zofia Charszewska, Janusz Korczak, Konstanty Ildefons Gałczyński i inne osoby.

\section{Wartości wychowawcze czasopisma „Młody Spółdzielca"}

W artykule redakcyjnym pierwszego numeru „Młodego Spółdzielcy” z 1936 r. czytamy, że w szkołach powszechnych, gimnazjach i szkołach zawodowych powstają liczne spółdzielnie uczniowskie, szkolne kasy oszczędności, spółdzielcze warsztaty. „W tych organizacjach - informowała redakcja pisemka - młodzież zrzesza się podobnie jak dorośli, aby drogą współpracy i samopomocy zaprawić się do zgodnego życia w gromadzie, aby pracować bezinteresownie dla koleżanek i kolegów w szkole"3. Redakcja określiła cele i adresata pisemka, stwierdzając, że „Młody Spółdzielca” "chce być przewodnikiem działalności wychowawczej, organizacyjnej i gospodarczej spółdzielni uczniowskich [...], pragnie, być stałym doradcą i instruktorem spółdzielni uczniowskich, chce zawsze służyć radą i pomocą zarządom spółdzielni i nauczycielom - opiekunom"4.

Redaktorzy zapowiedzieli, że na łamach czasopisma będą zamieszczać wiadomości o ciekawej działalności spółdzielni uczniowskich w Polsce i za granicą oraz spółdzielni dorosłych, a także będą prowadzić pracę propagandową i wychowawczą. Te cele były realizowane poprzez treści publikowane w formie artykułów, opowiadań, wierszy, piosenek, inscenizacji, ilustracji, wskazówek do urządzania obchodów świąt i zebrań spółdzielczych w szkole oraz materiałów instruktażowych. Na łamach „Młodego Spółdzielcy” znalazły się opisy działalności spółdzielni uczniowskich, ich doświadczenia, trudności i kłopoty młodych spółdzielców, zapytania i wątpliwości. Od pierwszego numeru czasopisma redakcja zachęcała dzieci i młodzież do pracy w zakresie spółdzielczości, pisząc: „My - spółdzielcy idziemy do dziś dnia wytkniętą drogą. To może czynić każdy, to możecie i wy uczynić, stworzywszy w swojej szkole spółdzielnię. Jeżeli to dobrze będziecie robili, przyczynicie się do tego, żeby życie na świecie było lepsze, sprawiedliwsze, żeby więcej na świecie było radości, która wam się tak słusznie należy”.5.

\footnotetext{
${ }^{3}$ Art. red., Idea spółdzielcza, MS 1936, nr 1, s. 1.

${ }^{4}$ Tamże.

${ }^{5}$ S. T., Do młodzieży, tamże, s. 3.
} 
Teksty redakcyjne zapoznawały młodych czytelników z historią powstania europejskiego ruchu spółdzielczego oraz jego pionierami: Karolem Fourierem, Robertem Owenem, Stanisławem Staszicem ${ }^{6}$.

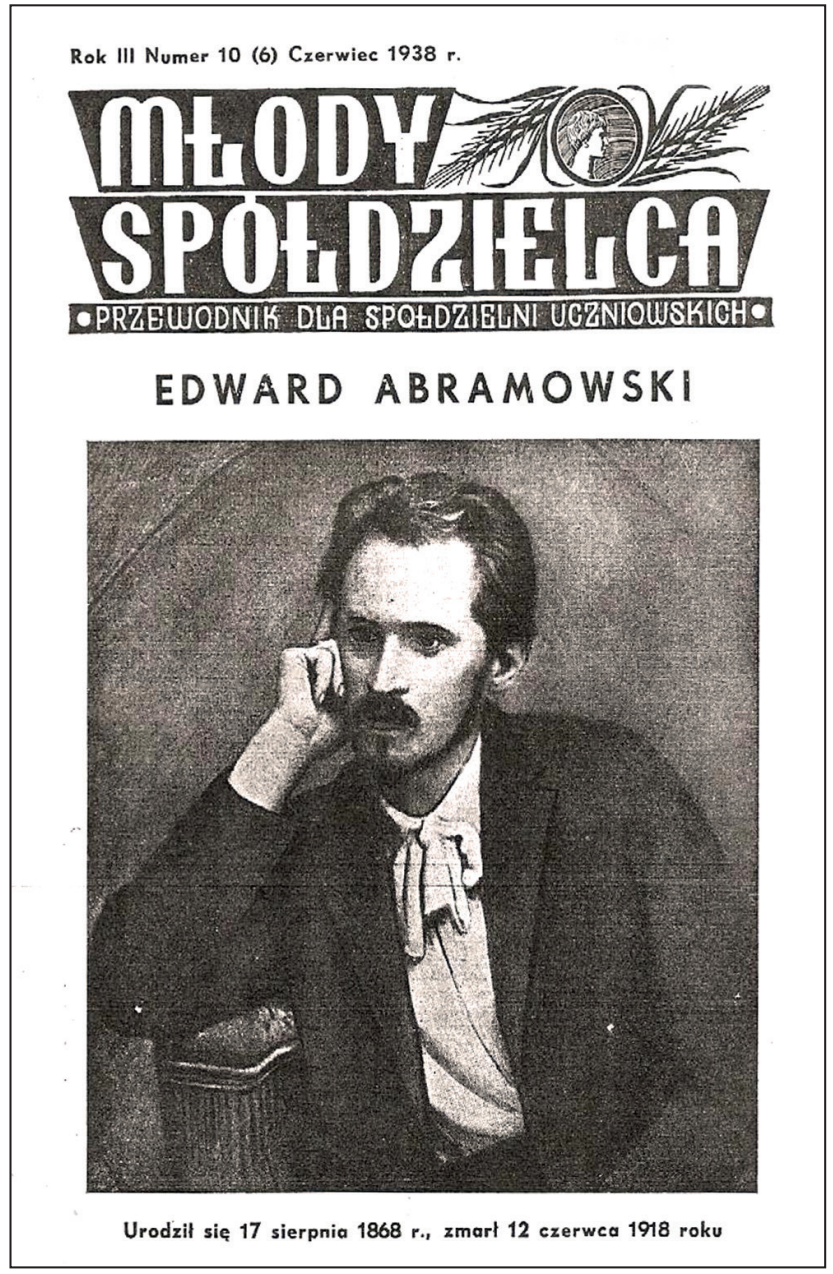

Fot. 1. Strona tytułowa czasopisma „Młody Spółdzielca” z czerwca 1938 r.

Przedstawiały uczniom twórców europejskiego i polskiego ruchu spółdzielczego: Edwarda Abramowskiego ${ }^{7}$ i Romualda Mielczarskiego ${ }^{8}$, twórców polskiej

${ }^{6}$ Art. red., Pamięci sprawiedliwych pionierów z Roczdelu, MS 1936, nr 5 (10), s. 1; art. red., Robert Owen - ojciec spółdzielczości, tamże, s. 5-7; M. O r s e t t i, Małe hordy i małe bandy Karola Fouriera, MS 1937, nr 3 (9), s. 4-7.

7 Edward Abramowski, MS 1938, nr 10 (6), s. 1; N. S a m o t y h o w a, W 20-tą rocznice śmierci Edwarda Abramowskiego, tamże, s. 4-5.

${ }^{8}$ Z. C h m i e l e w s k i, Romuald Mielczarski, MS 1937, nr 8 (3), s. 2; E. S z y m a ń s k i, Plon wyda każde zdrowe ziarno, tamże. 
spółdzielczości spożywców, Fryderyka Wilhelma Raiffeisena, ojca rolniczej spółdzielczości kredytowej w Niemczech ${ }^{9}$. Opisywały postać pioniera polskiej spółdzielczości rolniczej Franciszka Stefczyka i jego dzieło ${ }^{10}$. Z historią polskiego ruchu spółdzielczego były związane artykuły okazyjne, publikowane w dwudziestą rocznicę śmierci E. Abramowskiego czy dziesiątą rocznicę śmierci R. Mielczarskiego. Przy tej okazji pisano o ich zasługach dla spółdzielczości polskiej. Podkreślano, że R. Mielczarski „oddał się pracy nad spółdzielczością i w niej pozostał aż do śmierci"11.

Prezentowany miesięcznik zapoznawał czytelników z historią spółdzielczości uczniowskiej na ziemiach polskich pod zaborami. Pisano, że pierwsza spółdzielnia uczniowska w Polsce i prawdopodobnie na świecie została założona przez Jadwigę Dziubińską w 1900 r. wśród młodzieży wiejskiej na kursach ogrodniczych w Pszczelinie jako sklep koleżeński. Do tej młodzieży z wykładami na temat spółdzielczości przyjeżdżał E. Abramowski, twórca idei polskiego kooperatyzmu ${ }^{12}$. Analizowane czasopismo przybliżało doświadczenia innych spółdzielni uczniowskich, które powstawały na ziemiach polskich pod zaborami, a zwłaszcza spółdzielni założonej przez R. Klugego w Mińsku Mazowieckim i spółdzielni „Promień” zorganizowanej przez Bolesława Głuchowskiego w Rakowie ${ }^{13}$.

Artykuły redakcyjne prezentowały dzieciom i młodzieży dorobek polskiego ruchu spółdzielczego, a zwłaszcza spółdzielczości spożywców. Informowały o rozwoju i osiągnięciach „Społem” ZSSRP, programie Mariana Rapackiego, budowie Domu „Społem”14. Przykładem mogą być słowa K. Haubolda, który konkludował: „Widzimy, jak ożywioną, szeroką i pożyteczną była praca Związku „Społem” w jednym tylko 1936 r. Potężna ta instytucja jak i wyniki jej działalności powstały ze złączonych wysiłków dla wspólnego celu, podobnych do naszych skromnych wysiłków w szkolnej spółdzielni uczniowskiej”"15. Propagowaniu osiągnięć polskiego ruchu spółdzielczego był poświęcony dział zatytułowany „Co słychać w spółdzielczej Polsce?”, który zapoznawał dzieci i młodzież z różnymi rodzajami spółdzielczości w Polsce, jej osiągnięciami i wydarzeniami spółdzielczymi ${ }^{16}$. Dla przykładu - informowano o budowie magazynu towarowego „Społem” w Gdyni,

${ }^{9}$ H. D., Fryderyk Raiffeisen ojciec spółdzielczości kredytowej na wsi, MS 1937, nr 2 (8), s. 1.

10 P. P., Doktór Franciszek Stefczyk, MS 1936, nr 2 (7), s. 2-3; H. D., Pomóżmy sobie w biedzie, tamże, s. 4-5.

11 S. Th u g u t t, Twórca i jego dzieło, tamże, s. 2.

${ }^{12}$ E. M a g i e r a, Edward Abramowski jako twórca koncepcji polskiego kooperatyzmu, [w:] Wokół wybranych twórców idei pedagogicznych u zarania i w Drugiej Rzeczypospolitej, red. W. A n d r u k o w i c z, E. M a g i e r a, Szczecin 2012.

${ }^{13}$ Art. red., Wspomnienie sprzed 25 lat, MS 1937, nr 4 (10), s. 6; B. G ł u c h o w s k i, Jak to było w Rakowie, MS 1938, nr 10 (6), s. 5-7.

${ }^{14}$ K. H., Spółdzielnia spożywców - spiżarnia naszych matek, MS 1936, nr 5 (10), s. 2-3; E. J a s i ń s k a, Na 25-lecie Związku Społem, tamże, nr 3, s. 2-4; K. H., „Społem” w roku 1937, MS 1938, nr 8 (4), s. 5. Redakcja pisała: „W Warszawie, gdzie domów wiele, różnych domów - wspaniałych i skromnych, my też mamy dom, przyjaciele; spółdzielczy dom związkowy - ogromny!” (Dom „Społem", MS 1937, nr 10 (5), s. 1).

15 K. H., Rozwój Związku „Społem” w roku 1936, MS 1937, nr 10 (5), s. 3.

${ }_{16}$ M. D ą b r o w s k a, Wytwórczość spółdzielcza, MS 1937, nr 7 (2), s. 4-6; J. W., Spółdzielczość pracy, tamże, s. 9-10; art. red., Trochę danych o stanie spółdzielczości w Polsce, tamże, nr 10 (5), s. 22. 
dzięki któremu spółdzielczość spożywców rozwinęła handel międzynarodowy. „W polskim porcie - stwierdzano - rozwija się polska spółdzielczość"17.

Na łamach miesięcznika można odnaleźć sporo artykułów o treści gospodarczej, które zawierały informacje dotyczące odbudowy Polski, budowy Centralnego Okręgu Przemysłowego ${ }^{18}$, propagujące potrzebę rozwoju ekonomicznego $\mathrm{kraju}^{19}$. Jednocześnie zapoznawano uczniów z ruchem spółdzielczym na całym świecie, przedstawiając mapki, diagramy, dane liczbowe, pisząc, że w Polsce w porównaniu z innymi krajami „wiele mamy do zrobienia. $Z$ tym większym zapałem i ochotą działać powinnyśmy w naszej spółdzielni uczniowskiej, aby zaniedbanie to naprawić" 20 .

Artykuły redakcyjne spełniały funkcję wyraźnie propagandową, która polegała na zapoznaniu uczniów z podstawami ruchu spółdzielczego, jego historią i ideologią. J. Dominko wyjaśniał młodym czytelnikom: „Teraz już wiemy co to jest spółdzielczość: jest to stały wysiłek gromady ludzi, mających na celu wzajemną pomoc, przez prowadzenie wspólnego przedsiębiorstwa gospodarczego"21. Teksty redakcyjne ukazywały znaczenie pracy, współpracy, współdziałania i wzajemnej pomocy nie tylko dla członków samej spółdzielni uczniowskiej, ale również dla szkoły i środowiska lokalnego. Przedstawiały przykłady wspólnej pracy i jej znaczenia w szkole i w środowisku, jak choćby naprawianie drogi wiejskiej przez uczniów ${ }^{22}$. Uświadamiały, że wykonując wspólnie pracę, łącząc wiele drobnych sił, można osiągnąć wielkie rezultaty. Zachęcały do wspólnego podejmowania wysiłku na rzecz innych, rozwijania zaradności, zdobywania wiadomości i umiejętności. Przykładem były słowa J. Wolskiego, który pisał: „Bo im więcej będziecie mieli nauki i wiedzy, tym pożyteczniej potraficie pracować z czasem, gdy dorośniecie, dla społeczeństwa"23. Artykuły redakcyjne miały czasami charakter popularnonaukowy, w nich krzewiono zasady kooperatyzmu: wspólną pracę, współdziałanie, pomoc wzajemną. E. Szymański w jednym ze swoich wierszy publikowanych na łamach „Młodego Spółdzielcy” uświadamiał:

\author{
Sami zrobimy wszystko \\ Wspólnym, gromadzkim trudem. \\ Za szkołą będzie boisko, \\ Przed szkołą - nowy ogródek. \\ Będzie i tobie miło, \\ Gdy nam się wszystko uda. \\ Zobaczysz: wspólną siłą \\ Można budować cuda.
}

\footnotetext{
17 Art. red., W polskim porcie rośnie spółdzielczość, MS 1936, nr 1, s. 13.

18 W Centralnym Okręgu Przemysłowym, MS 1938, nr 6 (2), s. 16; F. B u r d e c k i, Centralny Okręg Przemysłowy, tamże, nr 8 (4), s. 2-4.

${ }_{19}$ Art. red., Budujemy nową Polskę, tamże, s. 1; art. red., O handlu zamorskim, MS 1937, nr 8 (3), s. 1.

${ }^{20}$ K. H., Spółdzielczość na szerokim świecie, MS 1936, nr 6, s. 4-6.

21 J. D o m i n k o, Co to jest spółdzielczość, tamże, nr 3-4 (8-9), s. 2.

22 Fotografia „Dzieci szkolne budują drogę przez wieś”, MS 1936, nr 3, s. 10; Fotografia „Pomagamy przy budowie szkoły", tamże, s. 11; A. T k a c z y k ó w n a, Lubelskie przoduje, tamże, s. 10-11.

${ }^{23}$ J. W ol s k i, Praca - wspólna zaradność, MS 1937, nr 7 (2), s. 2-3; E. S z y m a ń s k i, Rycerze pracy, tamże, s. 6-8;
} 
W każdym numerze „Młodego Spółdzielcy” zamieszczano wiersze i opowiadania, które ukazywały pracę spółdzielni uczniowskich, uwypuklały potrzebę współdziałania, uświadamiały, że każdy jest potrzebny i każdemu trzeba pomóc ${ }^{24}$. Podstawą każdego opowiadania była wspólna praca i zaangażowanie dzieci, dzięki któremu można osiągnąć rozmaite korzyści materialne, społeczne, kulturalne i inne. Opowiadania zawierały przykłady wspólnej pracy: założenia ślizgawki czy urządzenia zabawy karnawałowej ${ }^{25}$. W formie opowiadań zapoznawano dzieci i młodzież z pracą kas Stefczyka, popularyzowano spółdzielnie dorosłych, ukazywano zasady pracy spółdzielczej ${ }^{26}$. Przedstawiano możliwości zdobycia środków finansowych na udziały, dzięki którym można założyć spółdzielnię uczniowską ${ }^{27}$.

Zamieszczane teksty podkreślały znaczenie wspólnej pracy dla państwa i społeczeństwa, choćby na przykładzie budowy tamy na Sole w Porąbce czy Rożnowie ${ }^{28}$. Ukazywały dzieciom przykłady wspólnej pracy w innych krajach: w Danii, w której była wysoko rozwinięta spółdzielczość rolnicza i związane z nią uniwersytety ludowe ${ }^{29}$; w Holandii, gdzie ludzie wspólnym wysiłkiem budowali tamy, zapory, osuszali ląd ${ }^{30}$. Zachęcały dzieci i młodzież do nauki, żeby nie być ciężarem dla społeczeństwa. Ukazywały zadania oświatowe, stojące przed spółdzielczością uczniowską, które określono następująco: „nieść pomoc w pracy szkolnej, wychować uczniów i nauczyć pracy wspólnej, spółdzielczej, pożytecznej dla całego świata"31. Zadaniem spółdzielni szkolnych było szerzenie nauki i oświaty, dlatego miały one zakładać biblioteki, świetlice, propagować czytelnictwo książek i czasopism. Spółdzielca miał być zdrowym człowiekiem, dlatego czasopismo popularyzowało zdrowy tryb życia, właściwe odżywianie się i dbanie o higienę. Był to również kolejny obszar, na polu którego mogła działać spółdzielnia uczniowska. Pisemko publikowało inscenizacje na temat czystości, listy zadań w zakresie zdrowotności, przedstawiało spółdzielnie zdrowia za granicą ${ }^{32}$.

${ }^{24}$ Cz. C zaplińs ki, Pracujemy społem, MS 1937, nr 7 (2), s. 1; H. J a n u s ze w s ka, W słońcu, MS 1939, nr 7, s. 3-5; W. K i e ś I a ń s k a, Kłopoty Franka, MS 1936, nr 1, s. 4-5; M. W a s e ń c z u k, Janek sklepowym, tamże, nr 2, s. 5-6; G. M o r c i n e k, Złota pajęczyna, tamże, nr 3-4 (8-9), s. 3-6; Nasz kolega zachorował, MS 1937, nr 5 (1), s. 5; J. P o r a z i ń s k a, Wyście go uratowali, MS 1938, nr 2 (8), s. 3-6.

${ }^{25}$ H. H u s z c z y ń s k a, Nasza wspólna ślizgawka, MS 1937, nr 4 (10), s. 2-4; Z. C h a r s z e w s k a, List od Świętego Mikołaja, tamże, s. 4-5.

${ }^{26}$ C. D., Nie chcemy paprochów w mleku, MS 1936, nr 2, s. 4; S t a r y Do k t o r (J. Korczak), Co potrzebne, tamże, nr 1 (6), s. 3-4; H. H u s z c z y ń s k a, Jak to było w szóstej klasie, MS 1937, nr 8 (3), s. 5-7.

${ }^{27}$ H. C i e p I ín s k a, Zielska i grzyby, MS 1937, nr 10 (5), s. 4-5; M. B r z u s k a, Zbieramy kamienie, tamże, nr 1 (7), s. 3-4.

${ }^{28}$ Zbiorowym wysiłkiem ujarzmiliśmy żywioł, MS 1938, nr 7 (3), s. 1; G. M o r c i n e k, Zapora w Rożnowie, tamże, s. 2-4.

${ }^{29}$ K. W y s z o m i r s k i, Dania, spółdzielczy kraj rolników, MS 1937, nr 5 (1), s. 1-4.

${ }^{30} \mathrm{H}$. J a n u s z e w s k a, O gniewnym morzu i małomównych ludziach, MS 1938, nr 7 (3), s. 5-6.

31 K. H., Nasze zadania na polu oświaty, MS 1937, nr 3 (9), s. 11. Por. R. K I u g e, Oświata jest potrzebna, tamże, s. 1; K. L. Zakładamy biblioteki spółdzielcze, tamże, s. 11.

${ }^{32}$ M. K a c p r z a k, W zdrowym ciele - zdrowy duch, MS 1937, nr 6 (1), s. 1-2; J. K o r c z a k, Ład-Blask - Elegancja, tamże, s. 3-4; art. red., Nasze zadania na polu zdrowotności, tamże, s. 12; K. W y s z o m i r s k i, Spółdzielnie zdrowia w Jugosławii, MS 1936, nr 5 (10), s. 4-6. 




Fot. 2. Strona tytułowa czasopisma „Młody Spółdzielca” z listopada 1936 r.

$\mathrm{Na} ł a m a c h$ pisemka propagowano szkolnictwo spółdzielcze, a zwłaszcza Średnią Szkołę Spółdzielczą im. Romualda Mielczarskiego w Warszawie, której poświęcano artykuły, sprawozdania z obchodów świąt i rocznic ${ }^{33}$. Zachęcano do nauki w tej szkole, publikowano sprawozdania z działalności spółdzielni uczniowskiej i szkolnej kasy oszczędności tej szkoły ${ }^{34}$. Młodzież Średniej Szkoły Spółdzielczej w Warszawie drukowała sprawozdania z podejmowanych prac i wycieczek

33 T. R., W tęczowej szkole, MS 1936, nr 2, s. 3; Z. K a c z o r, Obchód ku czci R. Mielczarskiego w Szkole Spółdzielczej, tamże, s. 15.

${ }^{34}$ Art. red., Zapisujcie się do Szkoły Spółdzielczej, tamże, nr 3, s. 17; J. L u t e r e k, W Szkole Spółdzielczej im. R. Mielczarskiego, tamże, nr 2 (7), s. 8; Z działalności SKO uczniów Szkoły Spółdzielczej w Warszawie, MS 1937, nr 3 (9), s. 9. 
na łamach „Młodego Spółdzielcy”35. Jesienią 1936 r. w ramach propagandy spółdzielczości zorganizowała zawody balonowe o puchar „Młodego Spółdziel-

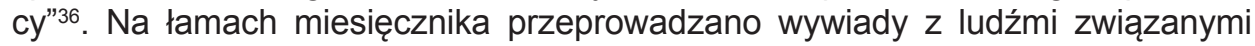
z polskim ruchem spółdzielczym. Drukowano wywiad z Franciszkiem Dąbrowskim, długoletnim kierownikiem Wydziału Społeczno-Wychowawczego Związku „Społem”, a potem dyrektorem Średniej Szkoły Spółdzielczości w Warszawie ${ }^{37}$.

W latach międzywojennych niektóre numery miesięcznika „Młody Spółdzielca" posiadały tematyczny charakter. Były poświęcone zdrowiu, dniu oszczędności i oszczędzaniu, dniu spółdzielczości i pracy. Tematyka czasopisma była związana z porami roku oraz kalendarzem świąt religijnych, państwowych i spółdzielczych. W numerach listopadowych znajdowały się treści związane ze Świętem Niepodległości, z okazji którego pisano: „Żyjemy w wolnej Polsce, w naszym wspólnym domu. Urządzamy się w nim tak, jak nam to odpowiada. Wielkie to dla nas szczęście"38. Numery grudniowe dotyczyły Świąt Bożego Narodzenia, organizowania choinek, robienia podarunków ${ }^{39}$. W numerach z początku roku kalendarzowego omawiano tradycje karnawałowe, organizowanie zabaw i zapustów ${ }^{40}$. Numery wydawane na wiosnę zawierały treści związane z Wielkanocą ${ }^{41}$, Świętem Trzeciego Maja ${ }^{42}$, Dniem Matki ${ }^{43}$. Redakcja miesięcznika reagowała na bieżące wydarzenia, np. publikowała informacje o śmierci papieża Piusa $\mathrm{XI}^{44}$ i wyborze Ojca Świętego Piusa XII ${ }^{45}$.

Numery październikowe pisemka były poświęcone oszczędzaniu i propagowaniu oszczędności. W artykułach, opowiadaniach, wierszach i inscenizacjach tłumaczono czytelnikom, na czym polega oszczędność, co można oszczędzać, czym jest planowanie pracy ${ }^{46}$. Pisano, że prawdziwa oszczędność to „rozumne gospodarowanie rzeczami - książkami, ubraniem, sprzętami w szkole, aby ich starczyło na dłuższy czas, by nasze skromne zasoby zużyć jak najlepiej"47. Podawano propozycje prowadzenia propagandy oszczędzania wśród dzieci i młodzieży ${ }^{48}$. Uświadamiano potrzebę oszczędzania i popularyzowano szkolne kasy oszczędności. Redakcja na stronie tytułowej numeru październikowego z 1936 r.

35 J. Ł o b a s z e w s k i, Zwiedzamy zakłady wytwórcze Związku „Społem”, MS 1936, nr 5, (10), s. 9.

${ }^{36}$ O. Fedoruk, Spółdzielcze zawody balonowe o puchar „Młodego Spółdzielcy”, tamże, nr 3-4 (8-9), s. 12.

${ }^{37}$ Art. red., Praca Związku wśród spółdzielni uczniowskich. Wywiad z p. Franciszkiem Dąbrowskim, tamże, nr 3, s. 3-6.

38 T. J., Rocznica Niepodległości, MS 1938, nr 3 (9), s. 3.

39 Tamże, nr 4 (10).

${ }^{40}$ E. S z y m a ń s k i, Zabawa, MS 1939, nr 6, s. 1; Art. red., Na ostatki urządzamy zabawę, tamże, s. 2; H. J., Zapusty, tamże, s. 3-4.

41 Tamże, nr 8, s. 1.

${ }^{42}$ E. Sz., Trzeci maj, tamże, nr 9, s. 2.

43 J. Ś w i ę c i c k a, Na Święto Matki, MS 1938, nr 9 (4), s. 1-2

44 Art. red., Zgon Ojca Świętego Piusa XI, MS 1939, nr 6, s. 13.

${ }^{45}$ Art. red., Ojciec Święty Pius XII, tamże, nr 7, s. 1.

${ }^{46}$ E. S z y m a ń s k i, Oszczędzamy!, MS 1936, nr 2 (7), s. 6-7; J. K o r c z a k, Ty taki, a ja taki, MS 1937, nr 2 (8), s. 4-5; N. K r z e p k o w s k a, Na Dzień Oszczędności, tamże, s. 6-7; Cz. B o g u sła w s k a, Oszczędzamy!, MS 1938, nr 2 (8), s. 7.

47 Art. red., Umieć oszczędzać - to sztuka, MS 1937, nr 2 (8), s. 2.

${ }^{48}$ J. Ś w i ę c i c k a, Jak wykorzystać okres oszczędzania w szkole, MS 1938, nr 2 (8), s. 8a-8b. 
pisała: „Nasza spółdzielnia, to warsztat pracy społecznej, w którym poznajemy, jak najlepiej gospodarować i oszczędzać"49.

Józef Dominko na łamach „Młodego Spółdzielcy” tłumaczył dzieciom i młodzieży, na czym polega oszczędzanie. Pisał: „Oszczędzam, tzn. poskramiam swoje zachcianki [...]. Oszczędzam, gdyż szanuję pracę ludzką. Jestem oszczędny, dlatego należę do spółdzielni uczniowskiej, gdyż ona kupując po cenach hurtowych, może zaoszczędzić środki finansowe na moje i innych potrzeby. Oszczędność każe szanować wysiłek człowieka, rozwija przyjaźń między ludźmi, wyrabia charaktery, zwalcza egoizm"50. Oszczędność propagował E. Szymański, który w jednym ze swoich wierszy konstatowa ${ }^{51}$ :

A my, spółdzielcy młodzi,
oszczędzamy gromadnie,
nikt z nas się nie zagłodzi
i grosz nasz nie przepadnie.

Realizacji celów wychowawczych służyły drukowane na łamach analizowanego pisemka przykazania młodych spółdzielców, które brzmiały następująco:

1. „Ja, młody spółdzielca, chcę tworzyć nowe życie, oparte na wspólnym szczęściu z innymi. dobro.

2. Nie będę więc wymawiał się od żadnej pracy, mającej na celu wspólne

3. Będę pamiętał, iż niespełnienie przyjętego obowiązku jest nieuczciwością.

4. Będę unikał niezgody, obmowy, gniewu - wszystkiego, co przeszkadza współpracy.

5. Nie będę zrażał się przeciwnościami, a postaram się jednać coraz nowych kolegów do współpracy.

6. Będę uczynnym i uprzejmym dla wszystkich i nigdy nie splamię ust kłamstwem.

7. Będę przekonywał innych, że zło ze świata da się usunąć tylko wspólnymi siłami.

8. Nie sławami, a czynem dowiodę mych przyrzeczeń"52.

Przez cały okres wydawania czasopisma na jego łamach można było odnaleźć krótkie fragmenty dzieł lub wypowiedzi twórców polskiego ruchu spółdzielczego. W ten sposób redaktorzy czasopisma dążyli do zapoznania czytelników z najważniejszymi i najbardziej znanymi ideami kooperatyzmu. Cytowano E. Abramowskiego, który głosił, że spółdzielczość zbuduje silny i mocny naród Polski ${ }^{53}$.

\footnotetext{
${ }^{49}$ MS 1936, nr 2 (7), s. 1.

50 J. D o m i n k o, Oszczędzaj mądrze!, MS 1936, nr 2 (7), s. 2.

51 E. S z y m a ń s k i, Sknera, tamże, s. 4.

52 Przykazania młodych spółdzielców, MS 1937, nr 10 (5), s. 7.

53 „Pokolenia, wychowane w kooperatyzmie, przesiąknięte ideą wspólnego dobra, przyjaźni i samodzielności - jest to nowa, oczekiwana, zapowiadana w proroctwach i pieśniach, demokratyczna, niezniszczalna Polska; naród silny i mocny" - pisał E. A b r a m o w s k i (MS 1936, nr 1, s. 1).
} 
Niemal w każdym numerze drukowano hasło spółdzielczości: Jeden za wszystkich, wszyscy za jednego ${ }^{54}$. Publikowano wypowiedzi F. Stefczyka, który nauczał, że: „Głównym hasłem ruchu spółdzielczego jest samopomoc i wzajemna pomoc stowarzyszonych, a zarazem ich solidarność i karność w dążeniu do wytkniętego celu”55. Cytowano R. Mielczarskiego, który stwierdzał, że: „Na drodze spółdzielczości tworzymy wielką i potężną Polskę Ludową, wielką bogactwem kultury, potężną zamożnością i uspołecznieniem ludzi"56. Przytaczano następujące słowa Józefa Beka: „Idea, tkwiąca w stowarzyszeniu, w społecznym małym sklepie, w naszym drobnym udziale, jest to tajemnicza siła, siła promieni słonecznych, ukryta w słońcu" ${ }^{\prime 2}$. Wymienione tylko nieliczne fragmenty wypowiedzi twórców ideologii spółdzielczości polskiej zamieszczane na łamach „Młodego Spółdzielcy” z jednej strony zapoznawały uczniów z zasadami kooperatyzmu, a z drugiej zawierały same w sobie duży ładunek wychowawczy.

\section{Praktyczne wskazania dotyczące wychowania spółdzielczego i działalności spółdzielni uczniowskich}

Redakcja pisma zachęcała uczniów i nauczycieli do organizowania obchodów Dnia Spółdzielczości, pisząc: „W dniu tym na specjalnych uroczystościach przedstawiamy wyniki naszych wysiłków całorocznych, stwierdzamy, że duch współpracy i współżycia szkolnej gromady potężnieje i że w spółdzielniach swoich wychowujemy się na dzielnych, dobrze przygotowanych obywateli naszego kraju"58. Czasopismo służyło pomocą w organizowaniu święta spółdzielczego. W numerach czerwcowych „Młodego Spółdzielcy” z okazji Dnia Spółdzielczości publikowano zabawy sceniczne i inscenizacje ${ }^{59}$. Ponadto przedstawiano sposoby dekorowania sal, zamieszczano hasła, piosenki i inne materiały. W postaci opowiadań, barwnym językiem, dostosowanym do młodych odbiorców przedstawiano obchody Dnia Spółdzielczości, wzory pogadanek na święto spółdzielcze i wiersze ${ }^{60}$. „W Dniu Spółdzielczości - pisał K. Haubold - poczujmy się częścią

${ }^{54}$ MS 1936, nr 1, s. 6; MS 1937, nr 11 (6), s. 1.

55 MS 1936, nr 2 (7), s. 5.

56 Tamże, nr 2, s. 1.

57 Tamże, nr 1, s. 5.

58 Art. red., W Dniu Spółdzielczości, tamże, nr 3, s. 2.

59 B. He rtz, Mieszkanie do wynajęcia. Bajka sceniczna, tamże, s. 8-9; t e n ż e, Awantura w tornistrze, MS 1937, nr 10 (5), s. 8-10; E. S z y m a ń s k i, Kto żwawy - do zabawy. Kto ochoczy do roboty, tamże, s. 10-12; b. a., Tęczowe promyki, tamże, s. 15-16; art. red., Organizujemy obchody wzorowo, tamże, s. 21.

60 J. He r b s t a, Dekoracje sali, MS 1937, nr 10 (5), s. 16-17; W. K i e ś I a ń s k a, Dzień Spółdzielczości zachęcił, MS 1936, nr 3, s. 6-7; E. S z e I b u r g-Z a r e m b i n a, Nasze święto, MS 1937, nr 10 (5), s. 7; J. W o s z c z a k, Na Dzień Spółdzielczości wzór pogadanki, tamże, s. 6-7. 
wielkiej rodziny spółdzielczej. Niech nasza, choć malutka spółdzielnia, będzie też ogniwem w kole, oplatającym świat cały"61.

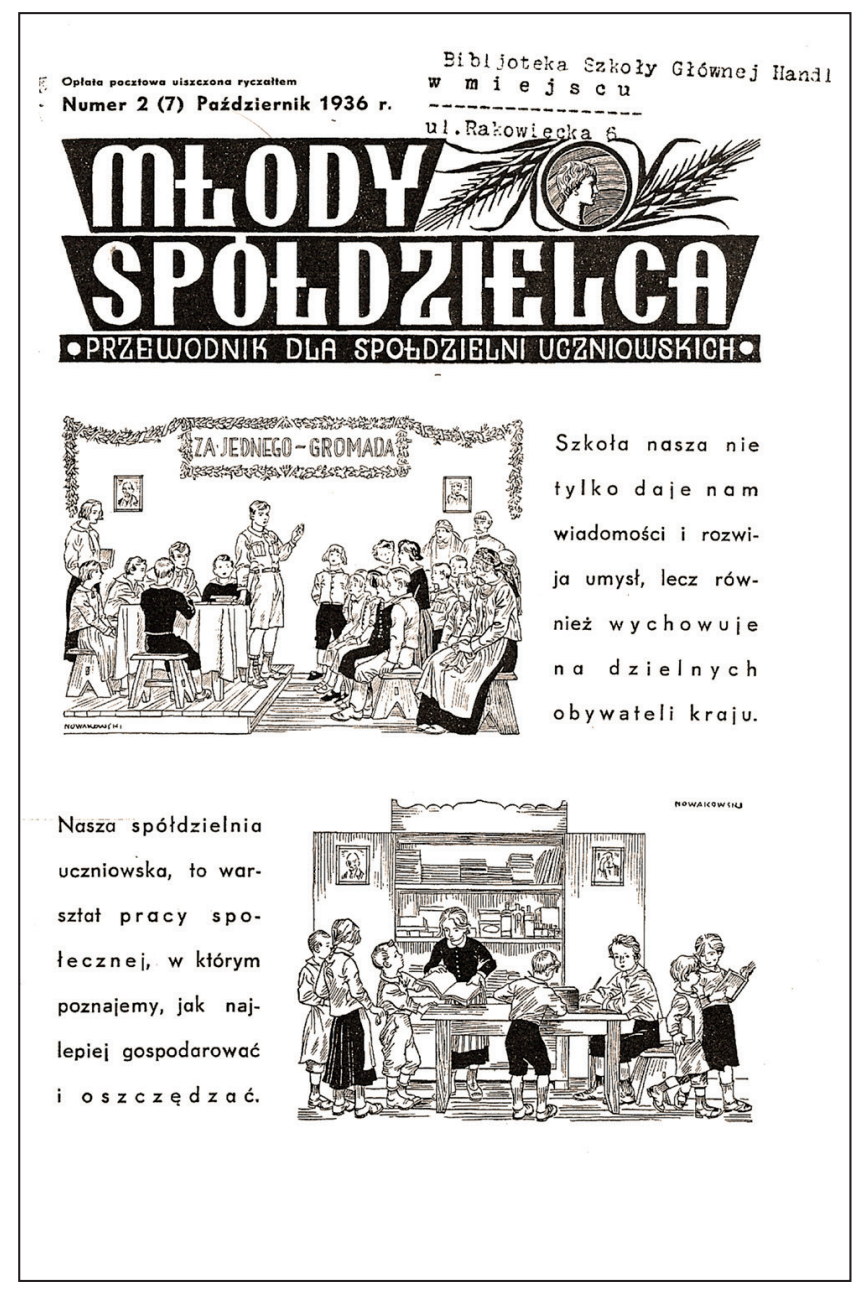

Fot. 3. Strona tytułowa czasopisma „Młody Spółdzielca” z października 1936 r.

Publikowano sprawozdania z obchodów Dnia Spółdzielczości przeprowadzonych w różnych szkołach i w różnych regionach Polski: z Katowic, Stanisławowa, Kraśnika, Płocka i innych miejsc ${ }^{62}$. Święto spółdzielcze obchodzono w Polsce od

${ }^{61}$ K. H., Na Dzień Spółdzielczości, MS 1937, nr 11 (6), s. 2.

62 Dzień spółdzielczości w szkołach, MS 1936, nr 1 (6), s. 8-10; Żyjący sklep w Lubomli, tamże, nr 3-4 (8-9), s. 13; M. W a s e ń c z u k, Przykłady obchodów w szkołach w Warszawie, MS 1937, nr 10 (5), s. 18; J. P o d s i a d I a n k a, Na Żoliborzu, tamże, s. 19; H. J a s i ń s k a, W Czerniakowie, tamże, s. 20; B. P a n a s i k, Obchody Dnia Spółdzielczości Wołkowysku, tamże, nr 1 (7), s. 5; Zarząd Spółdzielni „Pomoc”, Dzień Spółdzielczości w naszej szkole, MS 1936, nr 3-4 (8-9), s. 11; Krótkie sprawozdanie ze święta spółdzielczego, MS 1937, nr 3 (9), s. 10. 
1925 r., corocznie, jako uroczystość ogólnopolską, zazwyczaj w pierwszą niedzielę czerwca. Było ono ustanowione w 1923 r. przez Międzynarodowy Związek Spółdzielczy. Miało na celu propagandę spółdzielczości wśród całego społeczeństwa, żeby zachęcić dorosłych, młodzież i dzieci do spółdzielczości, przekonać o jej korzyściach i zjednać nowych członków63.

Obchodząc Dzień Spółdzielczości, dzieci i młodzież przygotowywała uroczyste apele, inscenizacje, wygłaszano referaty o tematyce spółdzielczej, przeprowadzano pogadanki, deklamowano wiersze, podejmowano konkretne prace społeczne, organizowano uroczyste przemarsze i barwne korowody. Z okazji Dnia Spółdzielczości w 1936 r. w Wilnie zorganizowano tydzień propagandy spółdzielczej, w czasie którego przeprowadzano doświadczenia z artykułami wyprodukowanymi przez spółdzielnię „Społem”, zorganizowano wystawę spółdzielczą, konkursy. Młodzi spółdzielcy sprawozdanie ze święta spółdzielczego zakończyli słowami: „Cała Polska święciła Dzień Spółdzielczości. I my także, bo wierzymy, że nadejście lepszych czasów można przyśpieszyć tylko w ten sposób, że wszyscy ludzie pracy na wsi czy w mieście przystąpią solidarnie do budowania organizacji spółdzielczych"64.

Sporo miejsca zajmowały przykłady działalności spółdzielni uczniowskich, publikowane w stałym dziale pisemka, zatytułowanym „Korespondencyjne doświadczenia”, który od września 1936 r. zmienił tytuł na „Z życia naszych spółdzielni". Ten dział był bardzo wartościowy dla młodych spółdzielców, ponieważ na przykładach zaczerpniętych z życia szkolnego zapoznawał uczniów z historią tworzenia poszczególnych spółdzielni szkolnych, ich organizacją, strukturą, pracą zarządów, osiągnięciami i trudnościami. Drukowano sprawozdania zarządów spółdzielni uczniowskich oraz napisane wartkim językiem przykłady działalności tych organizacji szkolnych ${ }^{65}$.

Ta część pisemka zawiera spory ładunek materiału źródłowego, przedstawiającego działalność poszczególnych spółdzielni uczniowskich z terenu całej Polski. Dla przykładu można podać spółdzielnię uczniowską „Przyszłość” w Rybniku, która rozpoczęła swoją działalność od niewielkiego sklepiku, mieszczącego się w niewielkiej szafce. Z czasem rozrosła się do dużej organizacji uczniowskiej, w ramach której oprócz sklepiku działała introligatornia, jadalnia, fryzjernia i inne agendy. Młodzi spółdzielcy w Rybniku założyli bibliotekę spółdzielczą, w czasie wakacji zorganizowali kolonie pracy, urządzili boisko szkolne, ślizgawkę, wyświetlali filmy spółdzielcze, organizowali akademie spółdzielcze, kursy języka francuskiego, kursy tańca. „Jakby było dobrze - wnioskował młody sprawozdawca Z. Pyzio - gdyby we wszystkich szkołach w Polsce istniały spółdzielnie uczniowskie. Jeśli zatem nie ma w waszej szkole spółdzielni, niech założenie jej stanie się

${ }^{63}$ E. M a g i e r a, Obchody Dnia Spółdzielczości w Polsce w okresie międzywojennym (19381939) jako czynnik wychowania młodzieży szkolnej, [w:] Szkice z teorii i praktyki wychowania w Polsce i w Norwegii w XX wieku, red. E. M a g i e r a, Toruń 2010, s. 103-126.

${ }^{64}$ Uczniowie $i$ uczennice ze Szkoły Powszechnej Nr 22, Tydzień propagandy spółdzielczej w Wilnie, MS 1936, nr 3-4 (8-9), s. 14.

${ }^{65}$ L. J a c h i m s k a, Już wiemy, co to znaczy „Społem”, MS 1936, nr 3, s. 12-13; Zarząd Spółdzielni „Pomoc”, I my pracujemy na Wołyniu, tamże, s. 11-12; L. K o w a I s k a, Na Pomorzu dobrze robią spisy towarów, tamże, s. 13. 
kwestią najbliższych dni! To, czego myśmy dokonali, to nic w porównaniu z tym, czego można dokonać"66.

W trzydziestu numerach „Młodego Spółdzielcy” publikowało swoje sprawozdania i wyniki pracy kilkaset spółdzielni uczniowskich, wśród których można odnaleźć m.in. spółdzielnię „Przyszłość” w Niekłaniu67, SKO w Szkole Spółdzielczej im. R. Mielczarskiego w Warszawie ${ }^{68}$, SKO w Szkole Handlowej Kaniowczyków ¡ Żeligowszczyków w Warszawie ${ }^{69}$, samopomoc leczniczą w Jaszczwi koło Jedlicza - uczniowską spółdzielnię zdrowia70, spółdzielnię uczniowską „Świt” przy Szkole Powszechnej nr 183 im. gen. Bema w Warszawie ${ }^{71}$, spółdzielnię uczniowską „Jedność” w Szkole Powszechnej nr 182 w Warszawie ${ }^{72}$, spółdzielnię uczniowską "Jedność" w Knyszynie ${ }^{73}$ i wiele innych. Same tytuły typu W całej Polsce pomyślnie rozwija się spółdzielczość uczniowska ${ }^{74}$ zachęcały do pracy w spółdzielczości.

Inny dział „Młodego Spółdzielcy” zatytułowany „Praktyka” ukazywał zasady działalności spółdzielni uczniowskich, w którym prezentowano podstawowe założenia pracy spółdzielni uczniowskich, dotyczące organizowania walnego zebrania, prowadzenia rachunkowości, kalkulacji, podziału funduszy i inne ${ }^{75}$. Pisano, że zgodnie z okólnikiem Ministerstwa WRiOP z 6 czerwca 1932 r. spółdzielnie uczniowskie zaliczono do przedsiębiorstw gospodarczych, które były zobligowane do płacenia podatku ${ }^{76}$. Zaznajamiano z zasadami organizacji szkolnych kas oszczędności, wskazywano na miejsca, w których można lokować oszczędności, informowano o Dniu Oszczędności ${ }^{77}$. Uświadamiano młodzieży różne możliwości działalności spółdzielczej na terenie szkoły. Spółdzielnie uczniowskie mogły istnieć w formie sklepiku szkolnego, szkolnej kasy oszczędności, introligatorni, fryzjerni, mogły zajmować się organizowaniem drugich śniadań, wydawaniem gazetki szkolnej i innymi niezaspokojonymi potrzebami na terenie szkoły ${ }^{78}$. Zachęcano do organizowania wycieczek do spółdzielni dorosłych ${ }^{79}$. W dziale „Praktyka”

${ }^{66}$ Z. P y z i k, Historia spółdzielni „Przyszłość” w Rybniku, MS 1936, nr 1, s. 7.

${ }^{67}$ Zarząd, Jak pracujemy w Niekłaniu, tamże, nr 1 (6), s. 6-7.

${ }^{68}$ Z życia szkolnych kas oszczędności w Warszawie, tamże, nr 2 (7), s. 8.

69 Tamże.

${ }^{70}$ S. B o ż e k, ucz. kl. Vl, O samopomocy leczniczej, MS 1937, nr 8 (3), s. 7; Dbajmy o zdrowie, MS 1938, nr 5 (1), s. 6-8.

${ }^{71}$ Zarząd, Porządek i plan panuje w Spółdzielni „Świt” przy Szkole Powszechnej Nr 183 w Warszawie, MS 1937, nr 8 (3), s. 9.

72 Ze Spółdzielni Uczniowskiej „Jedność” Szkoły Powszechnej Nr 182 w Warszawie przy ul. Bema nr 76, MS 1936, nr 1, s. 6.

${ }^{73}$ Zarząd, O spółdzielni „Jedność” w Knyszynie, MS 1937, nr 6 (1), s. 8.

${ }_{74}$ MS 1936, nr 5, s. 10.

${ }^{75} \mathrm{M}$. W a s e ń c z u k, O jednym walnym zgromadzeniu, tamże, nr 1, s. 8; J. W., Prowadzimy dobrze rachunkowość, tamże, s. 9.

${ }^{76}$ T. P o ź n i a k, Płacimy podatek państwu, tamże, nr 1, s. 9-10.

77 O. H a u b o Id, Spółdzielcza kasa oszczędności, tamże, nr 2 (7), s. 9; K. H., Gdzie składać oszczędności, tamże, s. 10; art. red., Dzień Oszczędności, tamże, s. 10.

${ }^{78} \mathrm{~S}$. A r cikiewicz, Organizujemy drugie śniadania, tamże, s. 11; Z życia szkolnych kas oszczędności w Warszawie, tamże, s. 8.

${ }^{79}$ H. R a c h ła n ó w n a, Wycieczka do Okręgowej Spółdzielni Spożywców w Wierzbniku, tamże, nr 3, s. 14; W. Ki éśla ń s k a, Wycieczka do Gdyni, MS 1937, nr 11 (6), s. 3-5; art. red., Urządzamy wycieczki do spółdzielni, tamże, s. 9; Z. C h a r s z e w s k a, Wycieczka do spółdzielni spożywców, MS 1938, nr 8 (4), s. 11-12. 
młodzi spółdzielcy i ich opiekunowie mogli znaleźć informacje dotyczące kalkulacji cen i kontroli sklepu ${ }^{80}$.

Drukowano kalendarz czynności związany z rozpoczęciem nowego roku szkolnego i podsumowaniem pracy spółdzielni uczniowskiej na koniec roku szkolnego ${ }^{81}$. Zawierano propozycje podziału wypracowanej przez spółdzielnię uczniowską nadwyżki finansoweje ${ }^{82}$ Na łamach czasopisma pojawiały się porady dotyczące prowadzenia rachunkowości, podziału pracy wśród członków spółdzielni, zakupu towarów do spółdzielni szkolnejes3. Podkreślano konieczność prowadzenia w spółdzielniach uczniowskich pracy społeczno-wychowawczej, która miała doprowadzić do zainteresowania spółdzielczością jak najszerszego grona uczniów. Temu celowi miały służyć obchody Dnia Spółdzielczości, świetlice, zebrania propagandowe, konkursy, czytelnictwo, kino szkolne, sztuki teatralne, inscenizacje, wycieczki spółdzielcze i inne formy popularyzacji zasad spółdzielczych. Podkreślano potrzebę stosowania metody poglądowej w propagandzie spółdzielczeje.

Na łamach „Młodego Spółdzielcy” zamieszczano instrukcje i przykłady takiej pracy społeczno-wychowawczej prowadzonej przez spółdzielnie uczniowskie na terenie szkół i w środowisku lokalnym ${ }^{85}$. Drukowano kalendarz pracy wychowawczej zawierający rozpisane zadania na poszczególne miesiące roku szkolnego oraz przykłady pracy wychowawczej realizowane przez spółdzielnie szkolne ${ }^{86}$. W artykułach od redakcji ukazujących się na początku roku szkolnego określano zakres prac dla spółdzielni uczniowskiej. W założeniach na rok szkolny 1936/1937 redakcja podkreślała potrzebę poznawania zasad spółdzielczych przez członków spółdzielni szkolnych, wychowywania się na światłych obywateli państwa i nabywania wiadomości, umiejętności spółdzielczych do przyszłej pracy w spółdzielniach dorosłego pokolenia ${ }^{87}$. Wraz z rozpoczynającym się nowym rokiem szkolnym zachęcano dzieci i młodzież do poszerzania struktur spółdzielni szkolnych, otwierania nowych działów, zaspokojenia wszystkich potrzeb uczniów za pośrednictwem spółdzielni szkolnej poprzez zorganizowanie fryzjerni, introligatorni, sekcji

80 S. A r c ik i e w i c z, Jak skalkulować cenę towarów, MS 1936, nr 2, s. 10; T. P o ź n i a k, Kontrolujemy dobrze sklepik, tamże s. 10-11; Z. C har s z e w s k a, Kłopoty skarbnika, MS 1938, nr 5 (1), s. 11-12.

${ }^{81}$ T. P o ź n i a k, Jak rozpocząć czynności w nowym roku szkolnym, MS 1937, nr 1 (7), s. 9-10; t e nż e, Kończymy nasze roczne rachunki, MS 1936, nr 3, s. 15; art. red., Co mamy do zrobienia w grudniu, MS 1938, nr 4 (10), s. 8c.

82 J. D o m i n k o, Jak podzielimy nadwyżkę - owoce naszej pracy, MS 1936, nr 3, s. 16.

83 T. P o ź n i a k, Jak rozpocząć rachunkowość, MS 1936, nr 1 (6), s. 11-12; M. W a s e ń c z u k, Podział pracy w spółdzielni, MS 1937, nr 8 (3), s. 15; Księgarz-spółdzielca, Gdzie kupować towary do spółdzielni, MS 1936, nr 1 (6), s. 12-13.

${ }^{84}$ Art. red., Metoda poglądowa w propagandzie, MS 1938, nr 6 (2), s. 13; art. red., Spółdzielczość uczniowska na filmie, tamże, nr 1 (7), s. 8.

${ }^{85}$ K. H., Prowadźmy prace wychowawczą, MS 1936, nr 3-4 (8-9), s. 15.

${ }^{86}$ P. S., Działajmy według planu, tamże, s. 15-16; O. H a u b o I d, Wesołe zajęcia w świetlicy, tamże, s. 16-17; art. red., Pomoce propagandowe, tamże, s. 17; Działalność wychowawcza spółdzielni „Jedność”, MS 1937, nr 11 (6), s. 8; Urządzamy choinki spółdzielcze, tamże, nr 4 (10), s. 12.

${ }^{87}$ Art. red., Z nowym rokiem, MS 1936, nr 1 (6), s. 1. 
śniadaniowej i innych form aktywności uczniowskiej. Zachęcano wszystkie spółdzielnie szkolne do podjęcia pracy oświatowej wśród swoich członków, polegającej na wygłaszaniu pogadanek, czytelnictwie czasopism i książek spółdzielczych, organizowaniu wycieczek do spółdzielni dorosłych. Proponowano dokonać reorganizacji zwykłych sklepików szkolnych na spółdzielnie uczniowskie ${ }^{88}$.

Dopełnieniem omówionego wyżej działu „Praktyka” był dział „Skrzynka pytań i odpowiedzi", który zawierał odpowiedzi na nadesłane przez czytelników pytania. W tej części czasopisma młodzi spółdzielcy mogli przeczytać wiele praktycznych wskazań, związanych z działalnością spółdzielni uczniowskich i znaleźć odpowiedź na pytania związane z szeroko pojętą spółdzielczością uczniowską. Redakcja wskazywała na kolejne czynności, związane z uruchomieniem nowej spółdzielni uczniowskiej i pracą spółdzielni uczniowskiej w nowym roku szkolnym. Podkreślała, że warunkiem prawidłowego funkcjonowania spółdzielni szkolnej było jej otwarcie, wybory władz, skrupulatne prowadzenie rachunkowości, kupno i sprzedaż tylko za gotówkę, odpowiednie zamawianie towarów i właściwe ustalenie cennika. Wskazywała na różne obszary życia szkolnego, które mogły być objęte przez pracę spółdzielczą. Podpowiadała, że spółdzielnie uczniowskie mogły zakładać biblioteki spółdzielcze, organizować choinki, nagrywać i oglądać filmiki z życia spółdzielni szkolnych, organizować wycieczki spółdzielcze, teatrzyki i inscenizacje. Zachęcano do zbierania grzybów i ziół oraz pokazywano przykłady spółdzielni uczniowskich, które podjęły taką pracę $e^{89}$. Udzielano porad w zakresie prowadzenia rachunkowości, organizowania spółdzielczej choinki, zakładania gazetki ściennej, fryzjerni, organizowania teatrzyków ${ }^{90}$. Zachęcano do współpracy spółdzielni uczniowskich ze spółdzielniami dorosłych, a szkolne kasy oszczędności do współdziałania z bankami spółdzielczymi ${ }^{91}$. W odpowiedzi na te zachęty młodzi spółdzielcy nadsyłali sprawozdania, w których pisali o podejmowanych działaniach. Spółdzielnie uczniowskie dokonywały zakupu radia, organizowały kino, poszerzały swoje struktury, zakładały szkolne kasy oszczędności, koła fotograficzne ${ }^{92}$.

Zachęcano uczniów do wzięcia udziału w ankiecie, na podstawie której określono na jakie cele spółdzielnie szkolne przeznaczyły nadwyżki ze swo-

\footnotetext{
${ }^{88}$ M. W a s e ń c z u k, Zamieńmy sklepiki szkolne na prawdziwe spółdzielnie, tamże, s. 2-3.

${ }^{89}$ M. B., Zbieramy grzyby, tamże, s. 13; M. Be r n e r ó w n a, Zielarstwo - nowy dział naszej pracy, tamże, nr 2, s. 9; J. T k a c z, Nasza spółdzielnia zbiera zioła, tamże, s. 8.

${ }^{90}$ K. H., Skrzynka pytań i odpowiedzi, tamże, nr 5, (10), s. 11-12; O. H a u b o I d, Spółdzielcza choinka w szkole, tamże, s. 13; O. H., Załóżmy gazetkę ścienną, MS 1937, nr 7 (2), s. 11; A. K a n i a, Zakładamy fryzjernię, tamże, s. 12; R. K I u g e, Organizujcie teatrzyki, MS 1938, nr 5 (1), s. 12-13.

${ }^{91}$ Art. red., Młodzi spółdzielcy - współdziałajcie z dorosłymi, MS 1937, nr 2 (8), s. 10; art. red., Współpraca szkolnej kasy oszczędności z miejscową kasą lub bankiem spółdzielczym, tamże, s. 10.

${ }^{92}$ E. R o s oł, Jak to Spółdzielnia Szkolna „Przyszłość” w Rybniku pracuje nad rozpowszechnieniem spółdzielczości, MS 1936, nr 3-4 (8-9), s. 10-11; J. W i e r z e j s k a, Radio - wspólnymi siłami, MS 1937, nr 8 (3), s. 8; P. R., Najlepsze radio zdobyte wspólną pracą, tamże, nr 3 (9), s. 2-3; K. D a n i e l e w s k a, Nasze kino, MS 1936, nr 3-4 (8-9), s. 13; pow., Spółdzielnia uczniowska „Światełko" przy szkole powszechnej w Rohatnej. Słonim, Nasza introligatornia, MS 1937, nr 2 (8), s. 8-9; Turystyczna Kasa Oszczędności, tamże, s. 9; Jak pracujemy w kole fotograficznym, MS 1938, nr 5 (1), s. 6; R. K I u g e, Koło fotograficzne przy spółdzielni uczniowskiej, tamże, nr 6 (2), s. 12.
} 
ich środków finansowych. Okazało się, że spółdzielnie uczniowskie ze swoich funduszy dofinansowywały choinki, zabawy szkolne, wycieczki, obchody Dnia Spółdzielczości, szkoły za granicą, budowę własnej szkoły, dokonywały zakupu odzieży dla uczniów mniej zamożnych, zakupu przyborów sportowych, pomocy naukowych, nagród, książek do biblioteki, radia, prenumerowały czasopisma. Ponadto fundusze spółdzielcze przeznaczano na dożywianie uczniów, płacono składki na rzecz PCK, LOPP, FON, działalność drużyny harcerskiej ${ }^{93}$.

Od roku szkolnego 1938/1939 zmieniła się struktura czasopisma. Dążąc do jego udoskonalenia, redakcja wprowadziła nową część zatytułowaną „Przewodnik dla opiekunów spółdzielni uczniowskiej” oraz „dział prac i robót, które mogą być wykonane przez młodzież dla jej własnej korzyści lub dla zdobycia funduszów na wspólne cele” i kącik twórczości dziecięce ${ }^{94}$. W dziale „Prace i robótki” można odnaleźć porady wraz z rysunkami związane $z$ samodzielnym wykonaniem różnorodnych przedmiotów użytkowych lub hodowli kwiatów ${ }^{95}$.

Część skierowana do opiekunów spółdzielni uczniowskich zawierała praktyczne rady związane ze sprawowaniem opieki nad spółdzielnią, m.in. dotyczące zamawiania towarów, prowadzenia ksiąg rachunkowych, organizowania kontroli w spółdzielni uczniowskiej ${ }^{96}$, zakładania gazetki ściennej, ogródków i hodowli ${ }^{97}$. Na łamach pisemka zastanawiano się nad możliwościami wykorzystania go w pracy wychowawczej spółdzielni uczniowskiej ${ }^{98}$. Proponowano nauczycielom organizowanie zespołów przysposobienia spółdzielczego dla młodzieży kończącej szkołę powszechną lub skierowanie jej na spółdzielcze kursy korespondencyjne ${ }^{99}$. Nauczyciele byli zapoznawani z wartościami wychowawczymi spółdzielczości uczniowskiej. „Wspólna praca - pisano - dla wspólnego dobra powinna uspołecznić młodzież, nauczyć ją podporządkować interesy jednostkowe interesom gromady, wdrożyć do wytrwałości i systematyczności w pracy"100. Informowano nauczycieli o spółdzielczych obozach letnich dla młodzieży, spółdzielczych kursach wakacyjnych dla nauczycieli101, ogólnopolskiej konferencji spółdzielczej dla

${ }^{93}$ K. H., Na jakie cele spółdzielnie uczniowskie przeznaczają swe nadwyżki, MS 1938, nr 10 (6), s. 10.

94 Od redakcji, tamże, nr 1 (7), s. 8a. Por., Przygody Jasia spółdzielcy, MS 1937, nr 3 (9), s. 9; Zagadka „winien - ma”, tamże, s. 9; tamże, nr 4 (10), s. 8-9.

${ }^{95}$ L. M., Jak zrobić sobie narty, MS 1938, nr 3 (9), s. 13-16; H. K i e d r z y ń s k a, Kilimek, tamże, nr 2 (8), s. 13-15; J. A s s m a n n, Ozdoby na choinkę, tamże, nr 4 (10), s. 14-15; Hodujemy pelargonie, MS 1939, nr 7, s. 14.

96 K. L., Księgi rachunkowe dla spółdzielni uczniowskiej, MS 1938, nr 1 (7), s. 8a-8b; M. M., Zamawiamy towary, tamże, s. 8b-8c; St. M., Kończymy rok operacyjny, MS 1939, nr 9, s. 8b-8d; O. H., Organizacja kontroli w spółdzielni uczniowskiej, MS 1938, nr 3 (9), s. 8a; J. D o m i n k o, Czynności komisji rewizyjnej w spółdzielni uczniowskiej, tamże, nr 4 (10), s. 8a-8b.

97 H. D., Zakładamy gazetkę ścienną, MS 1939, nr 6, s. 8a; J. R., Zakładajmy ogródki i hodowle, tamże, nr 7, s. 8a-8b.

98 H. D., Jak zużytkować „Młodego Spółdzielcę” w pracy spółdzielni uczniowskiej, MS 1938, nr 3 (9), s. 8b; art. red., Jak wykorzystać „Młodego Spółdzielcę”, MS 1939, nr 8, s. 8d.

99 Art. red., Jak pokierować młodzież kończącą szkołę, MS 1938, nr 1 (7), s. 8d.

100 H. D., Rola wychowawcza spółdzielni uczniowskiej, tamże, s. 8b.

101 A. K., Obóz spółdzielczy dla młodzieży pod Krzemieńcem, MS 1939, nr 8, s. 8b; art. red., Wakacyjne kursy spółdzielcze dla nauczycieli, tamże. 
nauczycieli, która odbyła się w kwietniu 1939 r. ${ }^{102}$ W ostatnim numerze wydanym w czerwcu 1939 r. pisano, że „Spółdzielczość wzmaga siłę gospodarczą narodu i obronność państwa"103.

Na łamach analizowanego miesięcznika zamieszczano zdjęcia z życia i działalności spółdzielni uczniowskich. Dla przykładu opublikowano fotografię przedstawiającą członków jednej z pierwszych spółdzielni uczniowskich w Polsce wraz z jej opiekunem R. Kluge, założoną w szkole powszechnej w Mińsku Mazowieckim w 1912 r. ${ }^{104}$ Drukowano również aktualne fotografie spółdzielni uczniowskich, ukazujące ich pracę, np. prace zarządu spółdzielni „Współpraca” w Szkole Powszechnej w Lubrańcu w powiecie włocławskim ${ }^{105}$. Same podpisy pod fotografiami typu Wre życie w spółdzielni uczniowskiej lub Przyjemnie jest na koloniach letnich, zorganizowanych przez spółdzielnię uczniowską zachęcały czytelników do pracy spółdzielczej. Zamieszczano ilustracje ukazujące współpracę w świecie fauny. Pod jedną z nich był podpis: Patrzcie, jak łatwo zwierzęta pojmują na czym polega zgodne współdziałanie ${ }^{106}$.

W poszczególnych numerach miesięcznika prezentowano zasady spółdzielczości w obrazkach: 1) Wszyscy mogą być członkami spółdzielni. Spółdzielnia jest stowarzyszeniem dobrowolnym ${ }^{107}$; 2) Każdy członek ma jeden głos bez względu na to, ile wpłacił udziałów ${ }^{108}$; 3) Sprzedaż w spółdzielni jest zawsze za gotówkę. Nie wolno kupować na kredyt ${ }^{109}$; 4) Spółdzielnia wypłaca zwrot kosztów od poczynionych zakupów ${ }^{110}$; 5) Spółdzielnie zawsze powinny prowadzić pracę wychowawczą ${ }^{111}$; 6) Do spółdzielni może należeć każdy112; 7) Udziały członków w spółdzielni nie są nadmiernie oprocentowane ${ }^{113}$.

W dziale zatytułowanym „Młodzi spółdzielcy za granicą” zamieszczano przykłady działalności spółdzielni uczniowskich w Europie i na świecie. Doświadczenia zagraniczne miały inspirować polskich uczniów do pracy spółdzielczej na terenie szkoły. Rozpoczynając ten dział, redakcja podkreśliła, że: „Możemy być dumni, bowiem pierwsze spółdzielnie uczniowskie powstały w Polsce i były wzorem dla wielu spółdzielni zagranicznych. Dzisiaj stanowimy część wielkiej szkolnej rodziny

102 A. K a c z o c h a, Konferencja spółdzielcza dla nauczycielstwa, tamże, nr 9, s. 8a.

103 Tamże, nr 10, s. 1.

104 Jak wyglądali nasi poprzednicy, MS 1936, nr 1, s. 10.

105 Z życia spółdzielni, tamże.

106 Tamże, s. 11.

107 MS 1937, nr 7 (2), s. 10.

108 Tamże, nr 8 (3), s. 9.

109 Tamże, nr 1 (7), s. 8.

110 Pod ilustracją czytamy: „Gdy nam spółdzielnia nasza od zakupów zwroty wypłaci, oj będzie radości masa - oszczędność wszystkich wzbogaci. Gdy grosz zabłyśnie na ręce, zrozumiesz wtedy kochanie, że kto kupował najwięcej, najwięcej złotych dostanie” (MS 1937, nr 2 (8), s. 7).

111 Pod obrazkiem widniał tekst: „Żeby członkowie spółdzielni mieli głowy nie od parady, spółdzielnia urządza dla nich odczyty, kursy, wykłady. Spółdzielcy muszą być dumą i chlubą całego świata, muszą być dzielni sercem, muszą być dzielni rozumem, a rozum przynosi oświata" (tamże, $\operatorname{nr} 3$ (9), s. 3).

112 Tamże, nr 4 (10), s. 2.

113 MS 1938, nr 6 (2), s. 6. 
spółdzielczej całego świata"114. Pisano, że spółdzielnie szkolne działały w Anglii, Belgii, Bułgarii, Czechosłowacji, Francji, Hiszpanii, na Litwie, Łotwie, w Polsce, Rosji, Rumunii, na Węgrzech i we Włoszech. Poza Europą spółdzielnie szkolne funkcjonowały w Stanach Zjednoczonych Ameryki Północnej, Kanadzie, Meksyku, Indiach i Afryce (w koloniach angielskich i francuskich).

Zaznajamiano polskich uczniów z różnymi formami pracy spółdzielni szkolnych za granicą, wśród których można było wyróżnić sklepiki uczniowskie, zaopatrujące uczniów w materiały do pisania i podręczniki szkolne oraz zbierające oszczędności. Inne spółdzielnie na terenie szkoły realizowały cele kulturalne, organizując przedstawienia filmowe i teatralne. W szkołach działały również spółdzielnie pracy, w których młodzież zajmowała się uprawą warzyw, zbieraniem ziół, jagód i grzybów, hodowlą zwierząt oraz spółdzielnie wytwórcze, których celem było wykonywanie przedmiotów z drewna, oprawa książek i prowadzenie różnych warsztatów. Szczególnie dużo miejsca poświęcano francuskiej spółdzielczości uczniowskiej, która była jedną z przodujących w Europie ${ }^{115}$. Ukazując spółdzielczość uczniowską w Europie, redakcja starała się uwypuklić rozwój, przydatność i atrakcyjność spółdzielni uczniowskich.

Interesującą częścią był dział „Co czytać?”, który popularyzował wydawnictwa z zakresu spółdzielczości. Drukowano reklamowe hasło: Kupujcie spółdzielcze książki dla młodzieży ${ }^{116}$. Zaznajamiano uczniów i opiekunów spółdzielni uczniowskich z książką F. Dąbrowskiego Spółdzielnie uczniowskie, która w latach międzywojennych doczekała się drugiego wydania w 1936 r., nakładem wydawnictwa „Nasza Księgarnia”. Była to bardzo cenna publikacja dla polskiego ruchu spółdzielczego, ponieważ zawierała ogół potrzebnych wiadomości, związanych z zasadami prowadzenia spółdzielni uczniowskich, ich celami, zadaniami, strukturą, rachunkowością i spisem literatury.

Zamieszczano spisy publikacji popularyzujące szkolne kasy oszczędności, m.in. książkę Piotra Załuskiego Jak zakładać i prowadzić Szkolne Kasy Oszczędności? (Warszawa 1932, wydanie II) oraz literaturę spółdzielczą dla dzieci. Polecano pracę Izy Nicholson, Promień słońca (Warszawa 1936), przy której napisano: „posiadać ją powinna każda biblioteczka szkolna, czyta się ją łatwo i szybko, a choć opowiada o dawnych czasach, mimowolnie postacie w niej występujące: mały Robert Owen, samotny Cooper, czy dzielni tkacze, ich żony i dzieci stają się naszymi przyjaciółmi, którym z całego serca chcemy pomóc i pracować razem z nimi"117.

Zachęcano do czytania książki Wacławy Kieślańskiej Za jednego gromada (Warszawa 1936), ukazującej historię spółdzielni uczniowskiej w Szarej Woli.

114 Art. red., Młodzi spółdzielcy za granicą, MS 1936, nr 1, s. 11; Spółdzielczość uczniowska na Łotwie, MS 1937, nr 11 (6), s. 11; Nie szkolne spółdzielnie, lecz spółdzielcze szkoły, tamże, s. 12-13.

115 O. D ą b row s k a, Francuscy szkolni spółdzielcy witają Międzynarodowy Kongres Spółdzielczy w Paryżu, MS 1937, nr 1 (7), s. 7-8; Z wycieczki do Paryża, tamże, nr 4 (10), s. 14; J. W., Na szerokiej drodze spółdzielczości uczniowskiej we Francji, MS 1938, nr 7 (3), s. 14-15; J. W a I s k a, Nad brzegami Indry i Loary, tamże, nr 10 (6), s. 14-15; tamże, nr 2 (8), s. 1.

116 MS 1937, nr 8 (3), s. 20.

117 O. D. H., Co czytać?, MS 1936, nr 5, s. 18. 
„Czytając tę książkę - stwierdzano - wierzymy, że dzieci z Szarej Woli wyrosną na dzielnych i silnych ludzi, na prawdziwie pożytecznych obywateli kraju"118. Prezentowano książkę Edwarda Szymańskiego ABC (Warszawa 1936), która w prosty, przystępny, wesoły i wierszowany sposób zapoznawała dzieci z zasadami spółdzielczymi. Na łamach „Młodego Spółdzielcy” pisano o niej, że: „Mówi o zgodnej i solidarnej współpracy, zbrataniu spółdzielczym ludzi całego świata, potędze pracy, radości tworzenia i działania dla dobra innych, konieczności nauki, produkcji, [...], itp." ${ }^{119}$ Polecano powieść dla dzieci J. Wolskiego Czy to bajka czy nie bajka (Warszawa 1934), ukazującą dzieje grupki chłopców, którzy pod wpływem nauczyciela zaczęli się „bawić” w spółdzielnię ${ }^{120}$. Omawiano książkę J. Korczaka Bankructwo małego Dżeka (Warszawa 1930), która opowiada z humorem historię pewnej amerykańskiej pseudospółdzielni, opartej na aktywności tylko jednego ucznia - Dżeka. Książka ta „ostrzega młodych spółdzielców przed niebezpieczeństwem, jakie przedstawia dla wszelkiej zrzeszonej pracy bierność ogółu i zachłanność poświęcania się jednostek"121.

Oprócz książek dla dzieci i młodzieży „Młody Spółdzielca” zawierał spisy literatury spółdzielczej dla nauczycieli-opiekunów spółdzielni uczniowskich, wśród których można odnaleźć prace E. Abramowskiego, Z. Chmielewskiego, M. Dąbrowskiej, J. Dominko, J. Jasińskiego, S. Thuguta, M. Rapackiego, M. Mielczarskiego, S. Wojciechowskiego. Wymienione pozycje zapoznawały nauczycieli z podstawami ideologicznymi spółdzielczości, genezą europejskiego i polskiego ruchu spółdzielczego, jego strukturą i zasadami. Prezentowane czasopismo również upowszechniało wśród nauczycieli wydawnictwa związane z wychowaniem dzieci i młodzieży w zakresie spółdzielczości. Do tej kategorii można zaliczyć prace S. Godeckiego, W. Hoszowskiej, F. Mittka, T. Poźniaka, A. Patkowskiego i inne. Polecano także kalendarze spółdzielcze ${ }^{122}$. Jednocześnie warto dodać, że miesięcznik „Młody Spółdzielca” wziął udział w akcji „Miesiąc przymierza z książką”, popularyzując książki dla bibliotek spółdzielni uczniowskich i dla bibliotek nauczycielskich ${ }^{123}$.

Czasopismo zawierało dział zatytułowany „Kronika”, który zaznajamiał czytelników z aktualnymi zagadnieniami z życia polskiego i międzynarodowego ruchu spółdzielczego. Pisano o obradach Międzynarodowego Związku Spółdzielczego, które odbyły się w Polsce we wrześniu 1936 r. ${ }^{124}$, o rozwoju spółdzielczości spożywców w Polsce ${ }^{125}$. Podawano dane statystyczne związane z działalnością spółdzielni uczniowskich. Dla przykładu w powiecie wieluńskim na 175 szkół powszechnych około 100 szkół posiadało spółdzielnie uczniowskie. W brzeskim okręgu szkolnym, na terenie województwa poleskiego i białostockiego na

\footnotetext{
${ }^{118}$ Ch., Co czytać?, tamże, s. 19; tamże, nr 3-4 (8-9), s. 19.

119 Co czytać?, tamże, $\mathrm{nr} 1$ (6), s. 14.

120 Tamże, nr 3-4 (8-9), s. 20.

121 Tamże.

122 Art. red., Spółdzielczy kalendarz książkowy, MS 1938, nr 1 (7), s. 8d.

${ }^{123}$ Miesiąc przymierza z książką, MS 1936, nr 3-4 (8-9), s. 24.

124 Art. red., Obrady Międzynarodowego Związku Spółdzielczego, tamże, nr 2 (7), s. 13-14.

125 Trzyletni plan „Społem” Związku Spółdzielni Spożywców RP, MS 1938, nr 5 (1), s. 16.
} 
2120 szkół powszechnych w 795 działały spółdzielnie uczniowskie. Redakcja czasopisma podkreślała, że spółdzielnie uczniowskie na tych terenach zaspakajały podstawowe potrzeby uczniów, przeznaczając część swoich dochodów na samopomoc koleżeńską ${ }^{126}$. Na terenie województwa śląskiego w roku szkolnym 1933/1934 działały 193 spółdzielnie uczniowskie, najwięcej w szkołach powszechnych, bo aż $161^{127}$.

W tej części redakcja czasopisma położyła nacisk na powiadamianie o planowanych kursach dla nauczycieli-opiekunów spółdzielni uczniowskich, trwających w czasie roku szkolnego oraz w okresie wakacji. Drukowano informacje na temat audycji radiowych o spółdzielczości. Przykładem może służyć słuchowisko radiowe przygotowane przez członków spółdzielni uczniowskiej „Przyszłość”, działającej w państwowym gimnazjum w Rybniku ${ }^{128}$. Audycje i słuchowiska radiowe stanowiły formę popularyzacji spółdzielczości uczniowskiej w Polsce. W kronice zamieszczano apele dotyczące zbiórki środków finansowych na szkoły polskie za granicą. "Musimy pomóc tej młodzieży. Musimy być solidarni z nimi w walce o utrzymanie polskości" - nawoływała redakcja pisma ${ }^{129}$.

$\mathrm{Na}$ łamach pisemka zachęcano spółdzielnie uczniowskie do wzięcia udziału w wystawie spółdzielczej, zorganizowanej w czerwcu 1936 r. przez „Społem” ZSSRP z okazji swego 25-lecia. Członkowie spółdzielni szkolnych byli zaproszeni do przedstawienia swojej pracy i dorobku w postaci eksponatów, fotografii, sprawozdań, wykonanych przez spółdzielnie uczniowskie przedmiotów, rysunków, plakatów, gazetek ściennych ${ }^{130}$. Wystawa spółdzielcza była formą popularyzowania spółdzielczości wśród dzieci i młodzieży, ponieważ zwiedzało ją wiele wycieczek szkolnych z całej Polski'131.

Ogłaszano konkursy, których celem było przedstawienie dorobku spółdzielni uczniowskich. Już w pierwszym numerze miesięcznika pisano, że redakcja „chce ułatwić dalekim i może nieznanym jeszcze spółdzielniom uczniowskim pokazanie tego, co już zdobyły i do czego doszły wspólnym wysiłkiem zrzeszonych członków"132. Publikowano prace konkursowe, ukazujące działalność poszczególnych spółdzielni uczniowskich, dla przykładu już w numerze drugim pisemka opublikowano konkursowe sprawozdanie z działalności spółdzielni uczniowskiej w szkole powszechnej w Czemiernikach w powiecie lubartowskim ${ }^{133}$. Zwracano się z pytaniem konkursowym do zarządów spółdzielni uczniowskich, jak należałoby zorganizować obchody Dnia Spółdzielczości ${ }^{134}$. Innym razem ogłoszono konkurs na opracowanie pogadanki spółdzielczej ${ }^{135}$.

${ }^{126}$ Art. red. Spółdzielnie uczniowskie na Polesiu i Podlasiu, MS 1936, nr 2, s. 14.

127 Art. red., Spółdzielczość uczniowska na terenie woj. śląskiego, tamże, nr 3-4 (8-9), s. 18.

128 Kronika, tamże, nr 1, s. 14.

129 Zbiórka na Fundusz Szkolnictwa Polskiego za Granicą, tamże, s. 14.

130 Art. red., Musimy wziąć udział w wystawie spółdzielczej, tamże, nr 2, s. 13.

131 Tamże, nr 5, s. 19.

132 Konkurs „Młodego Spółdzielcy”, tamże, nr 1, s. 15.

${ }^{133} \mathrm{Cz}$. Ku s e k, ucz. kl. VII, sekretarz spółdzielni „Jasne Słoneczko”, Z konkursu „Młodego Spółdzielcy", tamże, nr 2, s. 6-7.

134 Art. red., Zadania dla zarządów spółdzielni, tamże, s. 11.

135 Nowy konkurs „Młodego Spółdzielcy”, tamże, nr 1 (6), s. 15. 
„Młody Spółdzielca” jak każde czasopismo drukowało hasła reklamowe i reklamowało produkty wytwarzane przez polski ruch spółdzielczy. Reprezentatywne w tym zakresie były następujące hasła: Kupujcie książeczki spółdzielcze dla młodzieży; Używam tylko produkty z fabryk Społem ${ }^{136}$; Na gwiazdkę tylko smaczne cukierki i czekolada Społem ${ }^{137}$; Na książeczce Banku Społem leży moja złotóweczka. Cieszę się, że mam pieniądze i że «Społem» jest książeczka, Kupujcie na święta wydawnictwa spółdzielcze ${ }^{138}$. Reklamowano materiały i książki rachunkowe potrzebne w pracy spółdzielni uczniowskich, takie jak: księga główna, kasowa, sklepowa, udziałowa, karta członkowska, kwitariusz wpływów, bloczki sprzedaży i inne ${ }^{139}$. Ponadto niektóre numery zawierały wkładki-ulotki reklamujące spółdzielcze kursy korespondencyjne dla zespołów młodzieży oraz prospekty Gimnazjum Spółdzielczego im. R. Mielczarskiego w Warszawie.

\section{Wnioski}

Miesięcznik „Młody Spółdzielca” był organem polskiego ruchu spółdzielczości spożywców wydawanym w latach 1936-1939, skierowanym do dzieci i młodzieży - członków spółdzielni uczniowskich i ich opiekunów - nauczycieli. Czasopismo, posiadając dwie grupy adresatów, do każdej z nich kierowało swoje treści. Wobec nauczycieli-opiekunów spółdzielni uczniowskich „Młody Spółdzielca” - jak wskazywał sam podtytuł - odgrywał rolę przewodnika lub poradnika. Na łamach pisemka opiekunowie spółdzielni uczniowskich w sposób rzeczowy uzyskiwali najpotrzebniejsze porady związane ze sprawowaniem opieki nad spółdzielnią uczniowską, jej założeniem, organizacją, prowadzeniem, rachunkowością, zadaniami.

Młodzi spółdzielcy na łamach pisemka byli zapoznawani z genezą, historią, twórcami, rozwojem oraz osiągnięciami europejskiego i polskiego ruchu spółdzielczości dorosłych i spółdzielczości uczniowskiej. Język pisma był dostosowany do rozwoju i możliwości poznawczych dzieci. Próbowano w interesujący sposób ukazać dzieciom i młodzieży szkolnej problematykę spółdzielczą. Barwnym, żywym językiem autorzy tekstów zachęcali młodych czytelników do podejmowania aktywności na polu spółdzielczości, stosując przesłanie: Zobacz, jak oni to robią, mają z tego korzyści, uczą się i przy tym dobrze się bawią. Spróbuj i ty!

Czasopismo prowadziło dialog z młodym czytelnikiem, zachęcało do podejmowania pracy, do działania w spółdzielni uczniowskiej, którą ukazywało jako organizację szkolną, przynosząca korzyści materialne, ale również miejsce pracy, nauki i zabawy, spotkań towarzyskich i koleżeńskich, rozwijania współpracy i współdziałania oraz nabywania umiejętności społecznych i prozawodowych. Analizowane pisemko propagowało wartości polskie, narodowe,

\footnotetext{
136 Tamże, nr 2, s. 16; MS 1937, nr 1 (7), s. 16.

137 MS 1937, nr 4 (10), s. 16.

138 MS 1938, nr 4 (10), s. 8d.

139 MS 1936, nr 1 (6), s. 10.
} 
ale także wartości ogólnoludzkie, prawdę, dobro, piękno, troskę o innych, wzajemną pomoc, współpracę i współdziałanie.

Dokonana analiza treści tego miesięcznika pozwala stwierdzić, że było ono poświęcone przede wszystkim wychowaniu młodego pokolenia w zakresie spółdzielczości, kształtowaniu postaw prospółdzielczych, nabywaniu wiedzy spółdzielczej i umięjętności związanych z pracą w spółdzielni uczniowskiej. Oprócz wychowania spółdzielczego czasopismo brało udział w wychowaniu obywatelskim, patriotycznym, religijnym, ekonomicznym i społecznym. Popularyzowało wśród uczniów wiedzę z zakresu spółdzielczości oraz pełniło funkcję propagującą spółdzielczość wśród dzieci i młodzieży szkolnej oraz nauczycieli.

Współredaktorami tego czasopisma były dzieci i młodzież, która na jego łamach zamieszczała sprawozdania z działalności spółdzielni uczniowskich, raporty z obchodów Dnia Spółdzielczości, opisy działalności spółdzielni szkolnych, informacje o wydarzeniach w swojej spółdzielni, fotografie i inne prace. Współcześnie czasopismo „Młody Spółdzielca” stanowi cenne źródło do dziejów praktyki wychowawczej w Drugiej Rzeczypospolitej i może inspirować do podejmowania podobnych inicjatyw w rzeczywistości oświatowo-wychowawczej na początku XXI w. 